\title{
Jørgen Sonne
}

\author{
To digte
}

\section{DE STORE TRILLESPILLERE}

Det er nok kun om natten de kommer frem og spiller løs her ude, om dagen ser man dem aldrig, så brede og høje de må være, så de gemmer sig nok ovre i skoven? Men deres store trilleruller ligger ud over markerne, og de ser så i mørket, hvem af dem der kan kaste længst, helt op over bakken, så langt ud. Om vinteren går de bestemt under jorden og sover en god del af sommeren, først ved efterår kommer de frem igen, og kaster og triller over det hele, og der ligger deres ruller, så langt at de blir helt små at se. $\mathrm{Nu}$ og da lægger de dem på række, af og til er de taget væk. Men så er det at de går ned under jorden og roder om der lige til næste år. Det er nogen helt nye danskere!

\section{DEN ENSOMME RØDE SANGER}

Den står helt alene med sig selv, langt ude i marken, og den synger. Man kan høre den helt ude fra bakken og her ned, afogtil kommer der en bil forbi, som bare suser og kører forbi den. Den synger lige ud i luften, op i skyerne, sådan alene, og det ryster i den. Så kører den op ad bakken, ned ad bakken igen, frem og tilbage som om den ledte efter nogen der ude. Men der er aldrig nogen som kommer og synger sammen med den. Om aftenen lunter den hjem igen i skuret og synger ikke mere. Den er lige så stille blevet stum. 